- Entomologica Fennica. 15 October 1999

\title{
On a collection of Hymenoptera in Baltic amber, with the description of a new species of Pantolyta Förster, 1856 (Hymenoptera, Diapriidae)
}

\author{
Peter Neerup Buhl
}

On a collection of Hymenoptera in Baltic amber, with the description of a new species of Pantolyta Förster, 1856 (Hymenoptera, Diapriidae). — Entomologica Fennica 10: 187-189.

Two hundred and seventeen specimens of Hymenoptera in Baltic amber were studied. The distribution of taxa is discussed and Pantolyta antiqua sp. $\mathrm{n}$. is described.

Peter Neerup Buhl, Parmagade 36, st.tv., DK-2300 Copenhagen S, Denmark

Received 9 April 1998, accepted 11 May 1999

Recently, due to a generous loan from the Skagen Amber Museum (NCIR, curator Karin Nordmann), Mr. Stig Andersen at the Zoological Museum (University of Copenhagen) has investigated a large number of unstudied pieces of Baltic amber containing arthropods. After sorting them out to orders, Mr. Andersen kindly allowed me to study 217 pieces containing Hymenoptera. It was possible to determine most of them to different systematic levels, the taxa being distributed in the following way:

Cynipoidea: 2 spm.

Chalcidoidea: 49 spm., 12 of which belong with certainty to Mymaridae, 3 to Trichogrammatidae.

Heloridae: 1 doubtful spm.

Proctotrupidae: $1 \mathrm{spm}$.

Diapriidae: 20 spm., 6 of which belong with certainty to Diapriinae, 10 to Belytinae (1 Pantolyta sp. n., cf. below, 1 Acropiesta sp.), 4 are doubtful at the subfamily level.

Scelionidae: 27 spm. (mostly Scelioninae, only very few Teleasinae and Telenominae), 1 Amblyscelio sp., 1 Macroteleia sp., and 13 specimens belonging to Idris.
Platygastridae: $2 \mathrm{spm}$.

Ceraphronidae: $2 \mathrm{spm}$.

Megaspilidae: $6 \mathrm{spm}$.

Ichneumonoidea: $37 \mathrm{spm} ., 10$ of which belong to Ichneumonidae, 15 to Braconidae, the rest uncertain at the subfamily level.

Aculeata: $3 \mathrm{spm}$. impossible to determine further.

Chrysididae: $1 \mathrm{spm}$.

Dryinidae: $1 \mathrm{spm}$.

Bethylidae: $10 \mathrm{spm}$.

Formicidae: $10 \mathrm{spm}$.

Sphecidae: $1 \mathrm{spm}$.

Especially striking is the relatively large amount of Scelioninae, in particular Idris, which are very scarce in recent fauna. Bethylidae also is surprisingly common, whereas platygastrids are more scarce in the amber than should be expected from their commonness today. Larsson (1978) also noted that Bethylidae and Scelionidae are well represented in Baltic amber.

One of the most well-preserved specimens studied, belonging to the small diapriid genus Pantolyta (subfamily Belytinae), represents an undescribed species and is described below. 


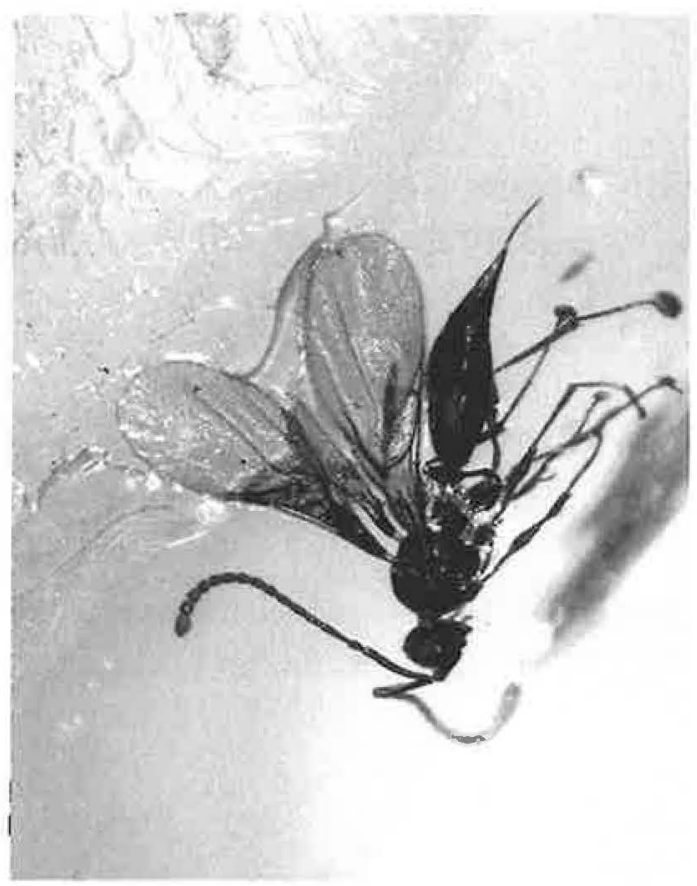

Pantolyta antiqua sp. n.

Type material. Holotype $\mathrm{E}$ found in northern Jutland (Denmark), preserved in the amber collection of the Zoological Museum, University of Copenhagen.

Diagnosis. A slender built species with relatively long antennae; first flagellar segment four times as long as wide, twice as long as pedicel; radialis strong, completely closing the radial cell. All seven known extant species of Pantolyta were revised by Macek (1993). These species all have A3 at most slightly longer than A2 (about 6:5); in antiqua it is twice as long.

Description of holotype. ㅇ. Body length 2.9 $\mathrm{mm}$. Colour blackish; antennae, mouthparts, eyes, legs, and metasoma slightly brighter.

Head in lateral view 1.1x as high as long; eye slightly higher than long (7:6), temple half the length of an eye; malar space equal to height of an eye; mandibles short, not forming a beak. Antenna with 15 segments; scape almost $1.2 \mathrm{x}$ as long as height of head, apically with weak angular corners; relative measurements of segments (length: width): I 19.0:2.2; II 4.0:2.2; III 8.0:2.0; IV 4.5: 2.0; V 4.5:2.0; VI 4.5:2.0; VII 4.0:2.2; VIII 4.0:2.5; IX 3.6:2.6: X 3.5:2.9; XI 3.5:3.0; XII 3.0:3.0; XIII 3.0:3.2; XIV 3.2:3.6; XV 6.5:4.0. Antenna with rather dense hairs which are hardly half as long as width of basal flagellar segments.

Mesosoma 1.4x as long as high; sides of pronotum smooth, epomia hardly present; mesoscutum with notauli and sparse long hairs; mesopleurae smooth, with a few hairs; scutellar fovea deep, about as long as wide, slightly widened anteriorly; scutellum with a few hairs; metapleurae and sides of propodeum with white pubescence; medial keel of propodeum not forked; dorsal areas of propodeum slightly longer than wide, virtually smooth and bare, lateral keels not ending in teeth.

Fore wing brownish, $2.9 \mathrm{x}$ as long as wide, nearly reaching apex of metasoma. Marginalis longer than its distance from basalis (15:11) and longer than the closed radial cell $(15: 13)$ which is about $0.5 \mathrm{x}$ as long as postmarginalis; radialis sclerotized throughout; cubitalis spurious, about as long as marginalis. Longest marginal cilia of wing equal to 0.1 width of wing. Hind wing without venation, $5.9 \mathrm{x}$ as long as wide; marginal cilia almost equal to 0.4 width of wing.

Metasoma 1.4x as long as head and mesosoma combined; petiole hardly longer than wide, with longitudinal carinae, ventrally with two pencils of hairs; T2 basally with some longitudinal furrows, this tergite and following tergites with a few hairs; metasoma pointed at apex, T7-T8 combined $3 x$ as long as T3-T6 combined. Second sternite not humped at base but with a tuft of dense pubescence, remainder of sternite as well as following sternites moderately hairy. Ovipositor exserted $0.7 x$ the length of T7-T8 combined.

Affinities. Due to the position of the unique specimen in the amber, it has only been possible to observe characters more or less visible in lateral view. Only one species of Pantolyta has been described from Baltic amber, $P$. somnulenta Maneval, 1938, which differs from antiqua in having shorter antennae, e.g. A3 only slightly longer than A2, marginalis shorter than radial cell, and radialis becoming feeble towards apex (Maneval, 1938). According to Maneval's figure, the metasoma is distinctly shorter in somnulenta than in antiqua, hardly more than $1.2 \mathrm{x}$ as long as head and mesosoma combined, and T7-T8 combined are only about $1.5 \mathrm{x}$ as long as T3-T6 combined, cf. Fig. 8 in Maneval (1938). 
Acknowledgements. My sincere thanks are due to Mr. Stig Andersen (Zoological Museum, University of Copenhagen) for the loan of material and photo.

\section{References}

Larsson, S.G. 1978. Baltic Amber - a Palaeobiological Study. - Entomonograph 1. - Scandinavian Science Press
Ltd., Klampenborg. 192 pp.

Macek, J. 1993. Revision of European Pantolyta Foerster (Hymenoptera, Diapriidae). - Folia Heyrovskyana 1(5): 41-51.

Maneval, H. 1938. Trois Serphoides de l'ambre de la Baltique. - Revue française d'Entomologie 5(2): 107-116. 